\title{
ECONOMIC AND SOCIAL SUSTAINABILITY OF REAL ESTATE MARKET AND PROBLEMS OF ECONOMIC DEVELOPMENT - A HISTORICAL OVERVIEW
}

\author{
Linda KAUŠKALE ${ }^{1}$, Ineta GEIPELE ${ }^{2}$ \\ ${ }^{1,2}$ Riga Technical University, Latvia \\ Corresponding authore-mail: Linda.Kauskale@rtu.lv
}

\begin{abstract}
Real estate market development and its sustainability are closely associated with history and development. Numerous problems have existed in society in the course of the years, including socio-economic problems. Real estate market development is also closely related to economic development, philosophical issues, and the analysis of these issues over the course of time makes it possible to explore both the historical development of these issues and the problems. The objective of the study is to analyze the main economic and real estate market development problems in the course of history by placing special emphasis on the economic development cycle and sustainability issues. Analysis, induction, deduction, historical and logical access methods were used in the research. Economic problems affect also the real estate market development, so the analysis of these problems is necessary in order to find possible solution opportunities.
\end{abstract}

Keywords: Cycles, economic development, economic problems, history, Latvia, real estate, real estate market, sustainability.

\section{INTRODUCTION}

Real estate market development and acquisition of real estate market as a whole is substantially associated with the purchasing power of the population, income splitting, formation of social strata in the course of time, and other issues, which are of great importance for the formation of economic thought. The objective of the study is to analyze the main economic and real estate market development problems in the course of the history, concentrating on the business cycle and sustainability issues. The main tasks of the research are as follows:

- To analyze the scientific literature and scientific articles on this topic;

- To explore the development of economic thought in Europe throughout history, as well as the most significant factors affecting the sustainability of real estate market;

- To explore the variety of cycles and to analyze and define the causes of the cycles;

- To make a historical survey of the Latvian economic development and to identify the development problems;

- To analyze sustainability, paying particular attention to economic and social aspects, to work out the levels of sustainable development and its analysis;

- To make conclusions and draft the proposals. 
Analysis, induction, deduction, historical and logical access methods were used in the research. Historical development of economic thought, types of cycles and reasons were explored in the study. The study involves the historical survey of real estate market economic, social and environmental sustainability, influencing factors and aspects. One of the problems was mentioned by Alfred Marshall (1890). He emphasized the fact that the number of scientific economists had always been relatively smaller comparing to the work to be done, and one of the causes might be the fact that the influence of economics on a better wellbeing of man has been overlooked.

There are a number of problems that should be solved nowadays which existed during the historical development of the society. The development of economic thought from a separate knowledge about economy up to knowledge systems, theories and schools was closely associated with the emergence of civilization and historical development from ancient times up until now (Krilovs, 2014), so the main economic and sustainable development issues were explored in the framework of this study, and these issues were approached in view of several aspects.

\section{SUSTAINABILITY AND GLOBAL CHALLENGES}

There are several problems in the economy and society, which should be solved. Various stable positive trends in the country, urban and economic development are important for sustainable development. During historical development, demographic factors have had a great influence on economic development of countries and each particular society. These factors are especially important nowadays. Forecasts show population increase up to 8 billions until 2024 and up to 10.85 billions until 2100 (Worldometers, 2016); at the start of agriculture, about $8000 \mathrm{BC}$, the world population was approximately 5 million, and significant is the fact that in 1970 there was roughly half of world population as compared to nowadays. The increase of world population is shown in Fig. 1.

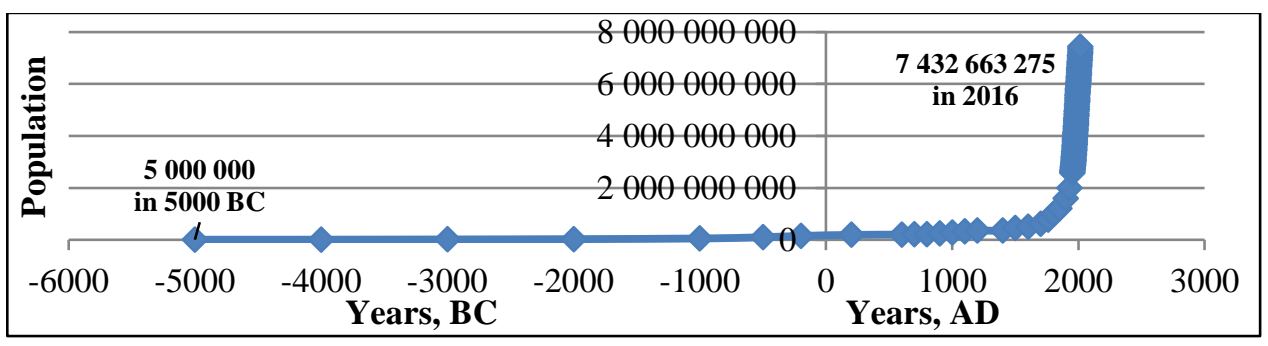

Fig. 1. The increase of world population from $5000 \mathrm{BC}$ to $200 \mathrm{BC}$ and from 200

AD to 2016 AD (Worldometers, 2016; United States Census Bureau, 2016; United Nations Population Division, 2001) (Figure created by authors).

The increase of population directly influences the development of real estate market, construction activities, real esate prices and housing affordability in general. Housing affordability has an important role from social aspect as it 
influences many inhabitants of the country. Social sustainability definitions are shown in Table 1.

Table 1. Definitions of social sustainability (Colantonio, 2009)

\begin{tabular}{|l|l|}
\hline $\begin{array}{l}\text { I. Sachs, 1999, } \\
\text { p. } 27\end{array}$ & $\begin{array}{l}\text { "A strong definition of social sustainability must rest on the basic values of } \\
\text { equity and democracy, the latter meant as the effective appropriation of all } \\
\text { human rights - political, civil, economic, social and cultural - by all people." }\end{array}$ \\
\hline $\begin{array}{l}\text { B. Littig and } \\
\text { E. Grießler, } \\
\text { p. 72 }\end{array}$ & $\begin{array}{l}\text { "A quality of societies. It signifies the nature-society relationships, and is } \\
\text { mediated by work, as well as relationships within the society. Social } \\
\text { sustainability is given, if work within a society and the related institutional } \\
\text { arrangements satisfy an extended set of human needs are shaped in a way } \\
\text { that nature and its reproductive capabilities are preserved over a long period } \\
\text { of time and the normative claims of social justice, human dignity and } \\
\text { participation are fulfilled." }\end{array}$ \\
\hline $\begin{array}{l}\text { M. Biart, 2002, } \\
\text { p. 6 }\end{array}$ & $\begin{array}{l}\text { "Sustainability aims to determine the minimal social requirements for long- } \\
\text { term development (sometimes called critical social capital) and to identify } \\
\text { the challenges to the very functioning of society in the long run." }\end{array}$ \\
\hline $\begin{array}{l}\text { M. Polese and } \\
\text { R. Stren, 2000, } \\
\text { pp. 15-16 }\end{array}$ & $\begin{array}{l}\text { "Development (and/or growth) that is compatible with harmonious evolution } \\
\text { of civil society, fostering an environment conducive to the compatible } \\
\text { cohabitation of culturally and socially diverse groups while at the same time } \\
\text { encouraging social integration, with improvements in the quality of life for } \\
\text { all segments of the population." }\end{array}$ \\
\hline
\end{tabular}

The society and its behaviour are changing with the course of time. Change is a problem of social science (Huntington, 1971). Especially important for society and market participants are changes in internal and external environment. Stoner and Freeman (1989) direct/indirect action environment model is shown in Fig. 2. The direct/indirect action environment model can influence also real estate and construction companies and the sector in general.

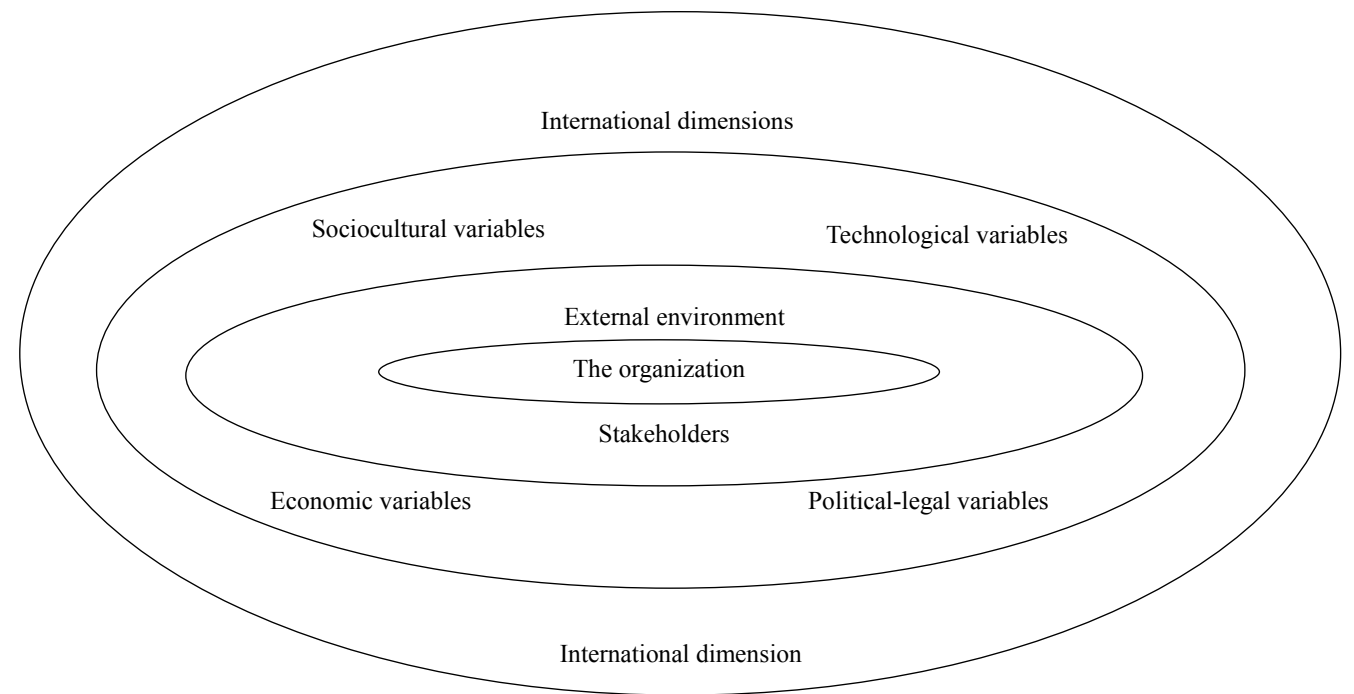

Fig. 2. Direct/indirect action environment model (Stoner \& Freeman, 1989). 
For example, for real estate investments especially important are ESG (economic, social, governmental) criteria and their implementation in risk management, including the selection of the type of investment strategy (with focus on active management of direct real estate investment and proxy voting and engagement for equity, debt and bonds investments) (CERES, IIGCC, INCR, PRI, UNEP Finance Initiative, RICS, 2016). The sustainability of real estate and construction sectors is determined by greenhouse gas emissions, construction and end-of-life waste generation and disposal effect, corrupt practices in planning, real estate and construction, availability and quality of housing (that is major life quality determinant) and lack of built-in human and labour rights safeguards (UN Global Compact, RICS, 2015). Demographic factors influence social aspects of sustainability the most, with direct and indirect influence on economics and environment. Due to the growth of population, especially important nowadays are the questions regarding sustainable construction. 30 assessment tools are described here, in world there are even more (Ding, 2012).

Economic aspects of sustainability are cruical for every inhabitant of the country. Countries worldwide can be classified and ranked according to economic sustainability index that is calculated by taking into account the GDP growth, debt levels, deficit/surplus, global competitive index (Zuleeg, 2010). The results for the European Economic Sustainability Index (EESI) for 2010 are shown in Table 2.

More important day to day become the questions of sustainable construction and related climate change. For instance, currently, South Africa is experiencing electricity crisis, and combined with the high level of solar irradiation and power utility now there is a need to reduce the country's peak demand through Demand Side Management, and as one of solutions the installation of solar water heaters in homes across the country was promoted (Chan Wing, Canha, \& Pretorius, 2015). Nowadays, green building construction is an important question, however, energy efficiency influencing decisions has motivating and contractionary factors (Kauškale \& Geipele, 2016). There are actitions that motivate and demotivate sutainable behaviour and decision making. Motivations for the incorporation of sustainability considerations are shown in Table 3.

The task of every country and society is to reach balanced and harmonic development in an integrated approach, including economic, social, environmental aspects and other influencing factors. 
Table 2. European Economic Sustainability Index (EESI) in 2007 and 2010 (Zuleeg, 2010, p. 6)

\begin{tabular}{|l|l|l|l|l|}
\hline Country & Score & Rank 2010 & Group & Rank 2007 \\
\hline Sweden & 0.55 & 1 & TOP & 8 \\
\hline Denmark & 0.45 & 2 & TOP & 4 \\
\hline Estonia & 0.45 & 2 & TOP & 1 \\
\hline Finland & 0.42 & 4 & TOP & 4 \\
\hline Netherlands & 0.28 & 5 & HIGH & 9 \\
\hline Germany & 0.24 & 6 & HIGH & 15 \\
\hline Luxembourg & 0.24 & 6 & HIGH & 7 \\
\hline Austria & 0.20 & 8 & HIGH & 13 \\
\hline United Kingdom & 0.07 & 9 & MIDFIELD & 11 \\
\hline Czech Republic & 0.05 & 10 & MIDFIELD & 17 \\
\hline Slovakia & 0.03 & 11 & MIDFIELD & 10 \\
\hline Poland & 0.02 & 12 & MIDFIELD & 15 \\
\hline Belgium & -0.01 & 13 & MIDFIELD & 22 \\
\hline Bulgaria & -0.02 & 14 & MIDFIELD & 12 \\
\hline France & -0.03 & 15 & MIDFIELD & 20 \\
\hline Ireland & -0.08 & 16 & IN DANGER & 3 \\
\hline Slovenia & -0.09 & 17 & IN DANGER & 19 \\
\hline Cyprus & -0.10 & 18 & IN DANGER & 23 \\
\hline Lithuania & -0.13 & 19 & IN DANGER & 6 \\
\hline Malta & -0.15 & 20 & IN DANGER & 21 \\
\hline Hungary & -0.17 & 21 & IN DANGER & 24 \\
\hline Romania & -0.19 & 22 & IN DANGER & 18 \\
\hline Latvia & -0.22 & 23 & IN DANGER & 2 \\
\hline Spain & -0.23 & 24 & IN DANGER & 14 \\
\hline Portugal & -0.29 & 25 & UNSUSTAINABLE & 25 \\
\hline Italy & -0.38 & 26 & UNSUSTAINABLE & 27 \\
\hline Greece & -0.93 & 27 & UNSUSTAINABLE & 26 \\
\hline & & & & \\
\hline & 0.25 & 27 \\
\hline
\end{tabular}

Table 3. Motivations for the incorporation of sustainability considerations

(Tsoulfas \& Pappis, 2012, p. 341)

\begin{tabular}{|l|l|}
\hline Internal drivers & External drivers \\
\hline Strategic management priority & Legislation and regulations \\
Employee involvement & Market pressure \\
Costing & Public pressure \\
Health and safety & Globalization \\
Marketing issues & \\
Profit opportunities & \\
\hline
\end{tabular}




\section{HISTORICAL OVERVIEW OF ECONOMIC PROBLEM AND INTERCONNECTION WITH REAL ESTATE DEVELOPMENT}

Ancient Greek philosopher Xenophon (430-355 BC) said that land was the main wealth, mother and nurse of all occupations (Krilovs, 2014). The market was governed by several laws and each country had different laws, which affected also the real estate market. The formation of first polises in Europe is closely associated with the history of ancient Greece. For example, in the 5th century BC, 30-50 thousand citizens (consider that only men were counted according to tradition, and real number of people was at least two times bigger) were living in Athens, while the number of citizens in some polises was around 2 thousand people, and with the development of polises, the surrounding villages were founded, but the polis center was developing as a city - an administrative and cultural centre, by maintaining and strengthening its defensive properties - in this respect, polis had a similar range of functions as ancient settlement later in the Atlantic Europe or in the Baltics. This settlement was called acropolis only in Greece (from the ancient Greek - "upper town") (Kḷaviņš, 2012).

Real estate market development was not uniform and acceptable for all. For example, when the rapid economic and social progress in Athens and other Greek polises reached its upper limit and the limited lands were mostly concentrated in the hands of a small number of owners, which turned into a kind of monopolists and leased the land for high prices to the farmers, and if the farmers could not pay the land lease, the land owners sold them into slavery along with their family members (Kḷaviņš, 2012). The poorest layers were preparing for a revolution in order to achieve wealth redistribution in their favour, and the ancient Greek civilization was facing economic and political disaster. At that time Solon initiated the demographic reform (Kḷaviņš, 2012). Throughout history, human relationships were described in epics. For example, the life customs were described in Homer's works $(9.8 \mathrm{BC})$, the Iliad and the Odyssey. Land conquering, impairment of dignity and wealth enhancement were the main reasons for wars. In ancient stories and works, mythological elements were involved, God's involvement in the process was observed and other characterizing features were described. Economic thought was developing in several regions of the world - in Europe, China, India, South and North America, etc. The development of economic thought in Europe and in the West is reflected in Table 4.

Table 4. Main economic thoughts and schools (compiled by authors)

\begin{tabular}{|l|l|}
\hline $\begin{array}{l}\text { Ecnomic } \\
\text { thought }\end{array}$ & Description \\
\hline $\begin{array}{l}\text { Ancient } \\
\text { economic } \\
\text { thought }\end{array}$ & $\begin{array}{l}\text { Ancient Greece: Plato, Aristotel, Socrates, Xenophon, Epicurus and others. } \\
\text { Ancient Rome: Lucretius, Cicero, Seneka. } \\
\text { Babylone - the Code of Hammurabi (Babylonian law code), code of ancient } \\
\text { Mesopotamia (about 1750 BC). The Code consisted of 282 laws. Code deals } \\
\text { with matters of contract - the wages to be paid, also trade, slander, slavery, } \\
\text { duties of workers, theft etc. }\end{array}$ \\
\hline
\end{tabular}




\begin{tabular}{|c|c|}
\hline & $\begin{array}{l}\text { Ancient China: Pre-Imperial era (ca. } 10 \text { 000-221 BC), Early Imperial era (221 } \\
\text { BC to } 960 \text { AD) and Late Imperial era (960-1911 AD) (Active Anglo Chinese } \\
\text { Communications, 2016), Confucius, Laozi, Mencius and Mozi, who all lived } \\
\text { during the Eastern Zhou period (Violatti, 2014). } \\
\text { Ancient India: Parashara, Vyasa, vedic philosophy, sramana philosophy } \\
\text { (Kḷaviňs, 2012). }\end{array}$ \\
\hline $\begin{array}{l}\text { Medieval } \\
\text { economic } \\
\text { thought }\end{array}$ & $\begin{array}{l}\text { Thomas Aquino (Doctor of Theology, role of Christian school, } 1225-1274 \text { ). } \\
\text { Economic thought in Feudal society. }\end{array}$ \\
\hline $\begin{array}{l}\text { Mercantilism } \\
\text { school of } \\
\text { economics }\end{array}$ & 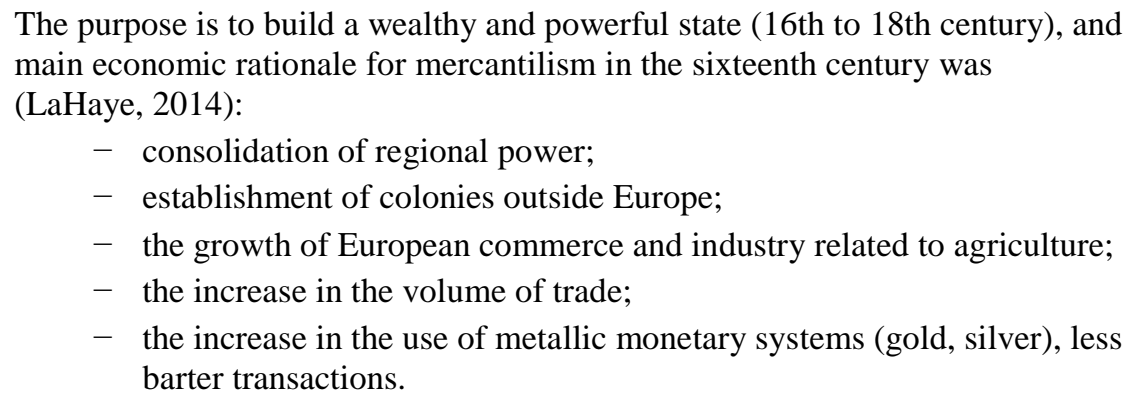 \\
\hline $\begin{array}{l}\text { Physiocrats } \\
\text { (from Greek - } \\
\text { "Government } \\
\text { of nature") }\end{array}$ & $\begin{array}{l}\text { Increasing income, by using land in best and most effective way, agriculture - } \\
\text { source of wealth. Less government intervention. } \\
\text { Vincent de Gournay (1712-1759); } \\
\text { François Quesnay (1694-1774); } \\
\text { Jacques Turgot (1727-1781) and others. }\end{array}$ \\
\hline $\begin{array}{l}\text { Classical } \\
\text { economic } \\
\text { school }\end{array}$ & $\begin{array}{l}\text { 17th to 19th century. Ideas of economic freedom, liberalism, "laissez-faire", } \\
\text { "laissez-passer". } \\
\text { Adam Smith analyzed (Krilovs, 2014): } \\
\quad-\text { division of labour, its productivity; } \\
\quad-\text { measurements of value; } \\
\quad-\text { income: wages, profits and rents; } \\
\quad-\text { capital and income productivity'; } \\
\quad-\text { social status: classes, their interests and other topics. } \\
\text { "Rent is that portion of the produce of the earth, which is paid to the landlord } \\
\text { for the use of the original and indestructible powers of the soil" (David } \\
\text { Ricardo, 1817). }\end{array}$ \\
\hline $\begin{array}{l}\text { Neoclassical } \\
\text { economic } \\
\text { school }\end{array}$ & $\begin{array}{l}\text { Neoclassical theory concerns: profits/employment/money/growth. } \\
\text { Key scientists: Karl Menger (marginal utility), A. Cournot (1801-1877), } \\
\text { Vilfredo Pareto (1848-1923), J. M. Keynes (1883-1946). }\end{array}$ \\
\hline $\begin{array}{l}\text { Keynesian } \\
\text { economics }\end{array}$ & $\begin{array}{l}\text { John Maynard Keynes (1883-1946), British economy, theory and practice of } \\
\text { modern macroeconomics, economic policies of governments. } \\
\text { - The General Theory of Employment, Interest and Money (1936). } \\
\text { - Fiscal and monetary policy tools: reduction of interest rates and government } \\
\text { investment in infrastructure. }\end{array}$ \\
\hline $\begin{array}{l}\text { Austrian } \\
\text { school }\end{array}$ & $\begin{array}{l}\text { Key scientists: J. Schumpeter (1883-1950), Ludwig von Mises (1881-1973), } \\
\text { Fridrich August von Hayek (1899-1992) and others. }\end{array}$ \\
\hline $\begin{array}{l}\text { German } \\
\text { school }\end{array}$ & $\begin{array}{l}\text { Key scientists: A. Wagner (1835-1917), M. Weber (1844-1920). } \\
\text { Old German school - K. Knies (1821-1898). } \\
\text { Jüngere Historische Schule - Gustav von Schmoller (1838-1917) and others. }\end{array}$ \\
\hline
\end{tabular}




\begin{tabular}{|l|l|}
\hline $\begin{array}{l}\text { Institutional } \\
\text { economics }\end{array}$ & $\begin{array}{l}\text { T. Veblen (1857-1929). Irrational market behaviour where consumers purchase } \\
\text { the higher-priced goods whereas similar low-priced (not identical) substitutes } \\
\text { are available (belief that higher price means higher quality (Veblen, 1899). W. } \\
\text { C. Mitchell (1874-1948) and others. }\end{array}$ \\
\hline $\begin{array}{l}\text { Modern } \\
\text { Economics }\end{array}$ & $\begin{array}{l}\text { James K. Galbraith (born 1952), A. Deaton (born 1945), Lawrence R. Clein } \\
\text { (1920-2013), Elinor Ostrom (1933-2012) and others. }\end{array}$ \\
\hline
\end{tabular}

Throughout history, special attention was also paid to ownership rights, because, according to A. Maslow (1954) pyramid, the need for housing is a basic need of every person. Hammurapi Code provided the death penalty for various types of crime - from the appropriation of property of another people up to misconduct (Kḷavinš, 2012, p. 24). The formation of social state was always of great significance for the development of the economic thought, because it was of socioeconomic importance. For example, in Indian "Vedas", "Mahabharata", "Manu"and other sources the society was divided into four varnas (castes) based on the responsibilities, morality norms and relationships with other groups - Brahmans (preachers), Kshatriya (soldiers) Vaisya (merchants), Sudra (Kḷaviňš, 2012, p. 36).

The establishment of the first cities was also significant for the real estate market development. As the oldest cities in different continents in the world can be mentioned Jerusalem (West Bank, Israel), Jericho (Palestinian Territories), Byblos (Lebanon), Allepo (Syria), Damascus (Syria), Argos, Athens (Attica, Greece), Susa (Iran), Faiyum (Egypt), Sidon (Lebanon), Plovdiv (Bulgaria), Luxor (Ancient Egypt, Greek name Thebes), Igodomigodo (Nigearia, Africa), Balkh (Afganistan), Samarqand (Uzbekistan), Ujjain (India), Xi`an (Shhaansi, China), Beijing (China), Chani (Creete, Greece), Lamaka (Cyprus), Kutaisi (Georgia), Ternate (Indonesia), Upper Xingu (Brasil), Jericho (Palestinian Territories), Gaziantep (Turkey), Beirut (Lebanon), in North America oldest is Mexico city (Mexico) (The Telegraph, 2016a; Khan, 2016; Mark, 2014).

Several famous real estates are now among the seven wonders of the ancient world, and they have high cultural-aesthetic significance. The classic seven wonders include (Clayton \& Price, 1988; The Editors of Encyclopaedia Brittanica, 2015; Hornblower \& Spawforth, 2001; The Telegraph, 2016a):

- Great Pyramid of Giza;

- Hanging Gardens of Babylon;

- Statue of Zeus at Olympia;

- Temple of Artemis at Ephesus;

- Mausoleum at Halicarnassus;

- Colossus of Rhodes;

- Lighthouse of Alexandria.

The only ancient world wonder that still exists nowadays is the Great Pyramid of Giza, and this fact confirms the sustainability of this object and points to the high level of construction technologies and quality. Typical representatives of the medieval period are the following (The World of Wonders, 2016; The Telegraph, 2016b):

- Stonehendge;

- Colosseum; 
- Catacombs of Kom el Shoqafa;

- Great Wall of China;

- Porcelain Tower of Nanjing;

- Hagia Sophia;

- Leaning Tower of Pisa.

New Seven Wonders of the World are Machu Picchu (Peru), Pyramid at Chichén Itzá (Yucatan Peninsula, Mexico), Taj Mahal (Agra, India), Petra (Jordan), Christ Redeemer (Rio de Janeiro, Brazil) and others (World of New 7 Wonders, 2016).

Sustainability is expressed in the ability of some objects to be preserved up to the existing days. By using new construction approaches, the object sustainability and lifetime is not longer than of these properties of objects that were built several centuries ago. At the same time, modern materials and technologies are more complex and the largest global projects demonstrate high development level of construction and some real estate objects, such as Summer and Winter Olympic buildings, the Football World Cup buildings, some residential, retail and central business district buildings, such as Burh Khalifa in the United Arab Emirates, Marina Bay Sands Hotel in Singapore and many other objects.

Wars and struggles for power were closely connected with the conquest of land throughout the history. There are several reasons for that and socio-economic consequences. These processes took place practically throughout the whole history of development, the same as the expansion and acquisition of new colonies was one of the main ideas and objectives in mercantilism, which directly affected public and real estate market development. Modern economy is currently waiting for new studies and new fundamental discoveries. According to Ivars Brīvers (2009), it is necessary to make economics less dependent on external fluctuations and to turn productivity instead of the yield into the key factor of the evaluation of economic objectives. Modern economic systems are very complex and require multidisciplinary approach.

\section{ECONOMIC CYCLES, THEIR TYPES AND CAUSES}

Real estate market, as well as national economy has a cyclic development nature. There are several types of cycles. There exist more than 380 cycles in economy (Deineka, 2006). Modern economic science distinguishes long cycles (40-60 years), average cycles (7-11 years) and short cycles (3-5 years) (Gods, 2002). Economic fluctuations can be defined as the deviations of key economic indicators from a stable condition. The cyclicism can be especially well observed in price fluctuations. The summary of the price volatility promoting factors - the problems are shown in Table 5. 
Table 5. The summary of price volatility promoting factors - expert mentioned problem evaluation (Bruksle, 2013, p. 99)

\begin{tabular}{|c|c|c|}
\hline Situation in the market & Economic policy & Activity of enterprises \\
\hline $\begin{array}{l}\text { Lack of competition. } \\
\text { Small market. } \\
\text { Open market. } \\
\text { Lack of local raw materials. } \\
\text { Greater exposure to raw } \\
\text { material price fluctuations. } \\
\text { Dependence on the changes } \\
\text { in the global economy. }\end{array}$ & $\begin{array}{l}\text { Ineffective national tax } \\
\text { system. Government } \\
\text { decisions are not focused } \\
\text { on the development. } \\
\text { Absence of the real long- } \\
\text { term economic } \\
\text { development plan. } \\
\text { Monetary policy is } \\
\text { oriented to the exchange } \\
\text { rate, rather than on price } \\
\text { stability. }\end{array}$ & $\begin{array}{l}\text { Incorrect assessment of demand - } \\
\text { low production volume and too } \\
\text { high costs. } \\
\text { Insufficient production capacity } \\
\text { and efficiency compared to } \\
\text { foreign competitors. } \\
\text { Absence of the enterprise strategy. } \\
\text { Price adjustment efforts in the EU. } \\
\text { Variable overall price level. }\end{array}$ \\
\hline
\end{tabular}

In general, each cycle has the following phases:

- Prosperity is the highest point of economic growth; the economy has the maximum load; the lowest level of unemployment and full employment are observed; cyclical unemployment does not exist; the unemployment rate is approaching the natural rate of unemployment; resources are being used to the maximum.

- Recession starts with the declining demand and price level; The investment volumes are reducing during the recession. Reduced demand and purchasing power cause financial difficulties for part of the society and enterprises.

- Crisis point is reached when the recession stops, and when the lowest production volume, price level and employment rate are reached; the cyclical unemployment is existing and the pessimism of entrepreneurs can be often observed; the work optimization or withdrawal from the market is occurring. The economic crisis in some countries also affects the economies of other countries. Unemployment costs are economic (insufficient production of domestic GNP) and social, where the social costs are the following (Heinrich et al., 2000, p. 334):

- loss of skills;

- loss of self-esteem;

- loss of moral principles;

- mass and political unrest.

- Recovery or dynamism phase involves the increase in production volume and price level, gradual decline in unemployment, increase in investment volumes and overall demand, increase in business profits.

Capitalism, being an unplanned market system focused on profit, could not achieve a painless, crisis-free transition from phase to phase (Menshikov \& Klimenko, 1989, p. 161). Concepts of the cycles are presented in Table 6. 
Table 6. Concepts of the cycles (Menshikov \& Klimenko, 1989, p. 163)

\begin{tabular}{|l|l|}
\hline $\begin{array}{l}\text { Menshikov's and } \\
\text { Klimenko's }\end{array}$ & $\begin{array}{l}\text { Both turning points in the long wave have an internal economic } \\
\text { mechanism, which is ultimately determined by the difference between the } \\
\text { average and the individual rate of profit }\end{array}$ \\
\hline Mandel's Concept & $\begin{array}{l}\text { There is an endogenous explanation only of the upper turning point, } \\
\text { while the lowest point is determined by a combination of random, } \\
\text { external circumstances that cause a sudden rise in the general rate of } \\
\text { profit }\end{array}$ \\
\hline Gordon's Concept & $\begin{array}{l}\text { Economic factors play a secondary role in the determination of the lower } \\
\text { and upper turning points. The decisive role is played by social factors }\end{array}$ \\
\hline
\end{tabular}

There is a group of resulting variables that characterize the state of the economy as a whole: production, income, demand, savings, capital investments, consumption, capital and employment (Menshikov \& Klimenko, 1989, p. 254). Schumpeter's (1939) idea is an explanation of the fourth production factor along with the land, labour and capital - entrepreneurial spirit, and in Schumpeter's interpretation the entrepreneurial spirit takes the form of an innovative idea - how something can be done better than now. The implementation of this innovative idea makes profit, and a tendency to make profit is the basis of the capitalist economy, and he believed it to be more effective than the socialist economy, because it encourages the occurrence of innovative ideas (Krilovs, 2014). The periods of long waves may vary in different literature but the longest cycles can be often split into Juglar cycles, as they are considered as very important for the analysis of the cycle (Smirnov, 2012), so the cycles and information should be analyzed as a whole. As the economic systems are interlinked, economic cycles are affecting also the real estate market. The authors are developing the cycle analysis scheme (see Fig. 3), which is essential for the overall evaluation of the situation and analysis of the information.

The literature presents also the description of 18 years of real estate cycle every 18 years the culmination of a credit-fueled real estate (Hanke, 2010), as well as real estate market cycle characteristics and special features, including the lack of information (Vanags, 2010). The authors of the research believe that one of the challenges of sustainable development should be the analysis of the causes of the cycles and the affecting factors, such as (Deineka, 2006):

- innovations;

- fluctuation of cash amounts;

- economic cycles are impulses and shocks that destroy the economic balance and are causing the response fluctuations, consequences: demand shocks, world's raw material price fluctuations, changes in interest rates, changes in investment and consumer costs;

- changes in the investment amounts and multiplier-accelerator model were considered by Keynes (1936) as the main impulses.

The authors of the work are complementing the range of the causes and influencing factors by splitting them into PESTEL factors that are reflected in Table 7. 


\begin{tabular}{|c|c|c|c|c|}
\hline \multicolumn{2}{|c|}{$\begin{array}{l}\text { Social development } \\
\text { (including Forrster, Toffler } \\
\text { cycles) }\end{array}$} & $\begin{array}{l}\text { Global } \\
\text { processes }\end{array}$ & $\begin{array}{l}\text { State development } \\
\text { plan: } \\
\text { Fiscal policy, } \\
\text { Monetary policy, } \\
\text { Macroprudential Policy }\end{array}$ & $\begin{array}{l}\text { Economic development } \\
\text { analysis } \\
\text { (including the development } \\
\text { of the financial markets) }\end{array}$ \\
\hline \multicolumn{5}{|c|}{$\begin{array}{c}\text { PESTEL factors analysis (all levels - international, national, regional, urban (Grizans, 2015) } \\
\text { Economic cycles } \\
\text { Real estate market cycles }\end{array}$} \\
\hline $\begin{array}{l}\text { Analysis of long } \\
\text { waves, } \\
\text { Kondratieff (1922), } \\
\text { Schumpeter (1939) } \\
\text { and others }\end{array}$ & \multicolumn{4}{|c|}{$\begin{array}{l}\text { The Kondratieff wave or long technological cycle. The results of the research } \\
\text { stated not only the long waves of the economy outline, but also the link to the } \\
\text { technological leaps, wars and revolutions (Kondratieff, 1935; Koltashov, 2010): } \\
\text { - cycle duration ranged from } 48 \text { to } 55 \text { years, both of them involved } 2 \text { stages - } \\
\text { upstream and downstream; upstream waves are characterized by fast } \\
\text { industrial growth and frequent technological leaps; } \\
\text { - upstream periods are characterized by fast economic growth, downstream } \\
\text { cycles are characterized by the slowdown in growth rates, depression of the } \\
\text { national economy, price lowering; } \\
\text { - interest rate on the capital decreases, wages become lower, economic } \\
\text { development becomes unstable, the recession is getting longer, but growth } \\
\text { periods are shorter; } \\
\text { - downstream period implies less wars and revolutions. } \\
\text { Long cycles are caused by innovations (Schumpeter, 1939). }\end{array}$} \\
\hline $\begin{array}{l}\text { Infrastructural cycles, } \\
\text { Kuznets (1930) }\end{array}$ & \multicolumn{4}{|c|}{$\begin{array}{l}\text { Infrastructural investment cycle (Kuznets, 1930). } \\
\text { Kuznets' cycles- economic cycles with the characteristic period of } 15-20 \\
\text { (some believe 20-25) years. These cycles are also closely associated with the } \\
\text { renewal of the buildings and places of residence. Kuznets associated these } \\
\text { waves with the demographic processes, the flow of immigrants and emigrants, } \\
\text { therefore, these cycles are also known as demographic cycles (Kuznets, 1930), } \\
\text { Hypothesis was put forward that these cycles can be viewed as Kondratiev's } \\
\text { third harmonics (Korotayev \& Tsirel, 2010). American scientist M.Abramovics } \\
\text { described the fluctuations over the period of } 20 \text { years as the "multiplicative - } \\
\text { accelerative outline chain", which "generates" } 20 \text { years of fluctuations: income } \\
\rightarrow \text { immigration } \rightarrow \text { construction of buildings } \rightarrow \text { total demand } \rightarrow \text { income (GDP } \\
\text { growth stimulates the population growth, it leads to the increase in investing, } \\
\text { including the construction of buildings (Akaev, 2010). }\end{array}$} \\
\hline & \multicolumn{4}{|c|}{$\begin{array}{l}\text { Juglar fixed-investment cycle (Juglar, 1862): } \\
\text { - } \text { its duration is } 7-11 \text { years, which on average is } 9 \text { years. This interval was } \\
\text { observed in the global GDP amounts during the last } 30 \text { years of the 20th } \\
\text { century, while the minimum growth rates were observed during the crisis } \\
\text { years: 1973, 1982, 1991; } \\
\text { - Juglar cycles are short-term economic cycles, which are based on the } \\
\text { changes in money circulation. The fluctuations in the investment volumes } \\
\text { in fixed capital were observed during the cycle and Juglar particularly } \\
\text { stressed the changes in credit volumes; } \\
\text { - } \text { the depth of Juglar crisis depends on Kondratiev's wave phase. Juglar cycles } \\
\text { are also characterized by delays in information movement, and information } \\
\text { delays are greater than for Kitcin's cycle, so the cycles are longer. Juglar } \\
\text { considered the crisis phase as a factor for the recovery of the economy, price } \\
\text { reduction and liquidation of those companies, which were formed to } \\
\text { artificially meet the increased demand. }\end{array}$} \\
\hline Kitchin (1923) & \multicolumn{4}{|c|}{$\begin{array}{l}\text { The length of Kitchin inventory cycle is from } 3 \text { to } 5 \text { years. Kitchin's short } \\
\text { economic cycles were explained by the world gold stock fluctuations, but } \\
\text { nowadays these explanations are supplemented. The reason is the time delay in } \\
\text { the information movement, which affects the company decisions (Kitchin, } \\
\text { 1923). }\end{array}$} \\
\hline Other cycles & \multicolumn{4}{|c|}{$\begin{array}{l}\text { Liquidity cycles (CrossBorder Capital Ltd., 2012), project life-cycles and other } \\
\text { cycles. }\end{array}$} \\
\hline
\end{tabular}

Fig. 3. System of cycle information analysis (Figure created by authors). 
Table 7. Causes and Affecting Factors of the Cycles

\begin{tabular}{|l|l|}
\hline Factor & Description, criteria \\
\hline Political & Political reasons, wars, power distribution (from ancient times) \\
\hline Economic & $\begin{array}{l}\text { Fluctuations in cash flow, amount of money in circulation. } \\
\text { Economic cycles are caused by impulses and the shocks, demand and supply } \\
\text { shocks, the world's raw material (input) price fluctuations, changes in interest } \\
\text { rates, changes in investment and consumer spending, multiplier-accelerator } \\
\text { model, capital market development }\end{array}$ \\
\hline Social & $\begin{array}{l}\text { Development of society, employment, income distribution within society, } \\
\text { education, demographical, including net migration, population growth rate, } \\
\text { etc. }\end{array}$ \\
\hline Technological & $\begin{array}{l}\text { Major technological mistakes. } \\
\text { Innovations (significant are rare), new technologies and information about } \\
\text { them }\end{array}$ \\
\hline Environmental & Nature disasters and catastrophes, climate change; resource discovery etc. \\
\hline Legal & $\begin{array}{l}\text { Slow decision-making, bureaucracy, legal justice, etc. Or, vice versa, too rapid } \\
\text { decision-making, when market participants still cannot adapt, etc. }\end{array}$ \\
\hline
\end{tabular}

All this also affects the real estate market and the construction process, as well as its sustainability. On the example of economic, social and environmental aspects, it can be shown that these sustainability influencing factors may even be conflicting (Frini \& BenAmor, 2015). These factors are also interrelated to social theory, for example, Sergey Nefedov's (2004) mathematical model of preindustrial sociodemographic cycles tells that after the population reaches the ceiling of the capacity of land, its growth rate starts to decline towards zero values, and the system starts to experience significant stress, such as the decline of living standard of common population, and, though most complex agrarian systems had considerable reserves for stability, according to conducted research of historical development, within 50 to 150 years these reserves in many cases got exhausted and the system experienced a demographic collapse and different types of disasters, that lead to a considerable decline of population, and, as a result, free resources became available, the population growth resumed and a new demographic cycle started.

The Forrester cycles are used for the study of general laws of functioning of the global system; the period is 200 years, which is determined on the basis of five indicators: the number of the world's population; natural resource stocks; production of food products; pollution and capital investments. The capital investments refer to funds that characterize the level of economic development (Ovechkina \& Shulgina, 2012).

In addition to the above reviewed cycles, millennial Toffler cycles are known the 3rd wave began in the late twentieth century - the establishment of the new lifestyle and new society took place, but the main feature was the transition to renewable energy sources (Ovechkina \& Shulgina, 2012).

Technological factors are also essential. The first and second industrial revolutions in Europe have significantly affected the rapid growth over the last century. The main directions of the technologies in the 20th and 21st centuries were the following (Akaev, 2010): 
- 1940 to 1980 - atomic energy, green revolution, chemization, aircraft industry, automotive industry.

- 1980 to 2020 - microelectronics, computers, internet, microbial biotechnology, information technology, robotic equipment.

- 2020 to 2060 - nanotechnologies, alternative energy, including hydrogen energetics, global information networks, multimedia and others.

Here the authors conclude that real estate market analysis is inseparable from the analysis of the development of society and macroeconomic tendencies as well as PESTEL factors.

\section{HISTORICAL DEVELOPMENT OF ECONOMY AND REAL ESTATE MARKET AND ITS PROBLEMS: CASE OF LATVIA}

The real estate issues in Latvia appeared along with the emergence of people in Latvia, when they began to build the first settlements in the Latvian territory around the 9th century BC. It is believed that these were nomadic tribes of hunters who left their permanent settlements in the Southern Lithuania or even further south-west or south-east areas and made the new place as their permanent settlement (Tilde Encyclopaedia of Latvian History, 1998-2012).

Primeval people were living in stone caves; then people began to build dwellings, to tame wild animals; the first farmers appeared, active farming was taking place (Paegle, 1924). Then the Bronze Age came, which was followed by the Iron Age.

The discovery of metal and development of trade to a large extent transformed human life and contributed to inequality among people, and when a man became a livestock farmer and peasant and became richer, he increasingly came to fight the strangers who wanted to take away his wealth - then, in order to be better able to fight, several related, nearby living families joined in one tribe and chose from among their own the most agile, strongest and smartest as the leader, who led them to fight (Paegle, 1924). Houses of Latvians were located in large shaded forest glades, on shores of rivers and lakes, at the edges of burned clearings (Paegle, 1924).

Latvians did not build together in villages and hamlets, as did their neighbours, the Russians and Estonians - each Latvian village was apart from others in the middle of corn fields and meadows, ancient Latvians lived in small low huts with straw or reed roofs, other buildings stood beside the living house that differed a little; there was a wooden fence, high gate, and to defend themselves from enemies, Latvians began to build castles (Paegle, 1924).

"Town is a permanently and densely populated economic and administrative political urban centre of a territory with its own patrimonial area (town's rural district) and self-government" (History Encyclopaedic Dictionary, 2016).

Ludza is considered as the oldest town in Latvia that was chosen by Latgalian tribes for living already in the 1st millennium BC - that is evidenced by 14 settlements, more than 25 castle mounds and about 70 burial mounds. The name of Ludza was first mentioned in written sources in 1177 in "Hypatian Codex" of Kiev, 
where the fact about the son of Grand Duke Rurik was mentioned, who was born and baptized in Ludza (Ludza municipality webpage, 2016).

Riga for the first time was named as town in "Livonian Chronicle of Henry"in portrayal of summer events of 1201 (Heniňs, 2007). At Riga Livonian village on the right bank of the Daugava, the place chosen by Bishop Albert as place of residence, a large-scale urban development began (Heninšs, 2007).

The third oldest town in Latvia is Cesis. In 1207-1209, near Riekstu hill The Order of the Livonian Brothers of the Sword started the construction of a stone castle; at the beginning of the 13th century, next to the stone castle was forming the settlement of traders and craftsmen that already in 1221 was mentioned in writings as a known locality. When the Cesis Castle became the residence of the Order's Master in 1237, wide reconstruction of the Castle was started. At the same time construction was expanding in the adjacent village. In 1323, Cesis was mentioned as a town; at the end of the 13th century Cesis town was surrounded by a concrete wall and fortification towers (Cēsis Municipality webpage, 2016).

Speaking about the history of Riga town, for example, the fire on 26 July, 1297, razed Riga (Heniňš, 2007), that was also a relevant social economic factor affecting the construction as well as the real estate market. In 1301, following the order of Pope Boniface VIII, the Livonian Order returned to the Archbishop of Riga Izarnus (Isarnus Tacconi) previously deprived castles and estates, and in 1335, by the order of the Pope the Livonian Order the deprived properties of the Riga Archbishopric were returned as well (Heninšs, 2007).

In general, speaking about the territory of Livonia, in terms of the Livonian territory it was ruled by (Spekke, 1935, p. 47):

- German Order, Riga Archbishopric (and associated bishoprics), from the 12th century till 1561 (Livonia). During that time essential are the selfauthorities of the Hanseatic cities (especially of Riga);

- Polish-Lithuanian Commonwealth, 1561-1772 (in part of the territory);

- Duchy of Courland as an autonomous Polish-Lithuanian vassal (15621795);

- Sweden, 1621-1721 (in part of the territory);

- Russian Empire (with the self-authority of the Baltic provinces), 17211918;

- Denmark (shorter period of time).

The collapse of the Livonian Confederation is generally considered as the end of the medieval period in Latvia (Kḷaviņš, 2012). In Livonia feudalism was the ruling public system that affected the system of property rights.

"Feudalism (from Latin feoudum) was a decentralized state power in favour of the local authority, and especially privileged persons, communities or corporations in conditions of senioral monarchy where the hierarchy of power was built on the basis of feudal system by the conclusion of contracts between the County lord (Senior) and slow man (vassal), where one gave feud or county (that is - the possession), while the other paid off by performing certain duties" (Kḷaviņš, 2012, p. 91). During the 15th to 19th centuries there was the serfage that essentially affected the system of the real estate market. 
Serfage: "The dependency of Livonian peasantry from landowners or land lords started to develop in the middle of the 15th century when the corvee-manors started to develop. During the 15th century the cereals of Livonia were requested and well-paid export goods. The nobles tried to increase profits, expand the lands and secured the workforce. The nobles began to regard their county farmers as their private nationals and considered the owners of their inherited homesteads as tied to that area. Thus, the landlord inherited for family not only a manor but also the peasants living in the manor's district or feud. The peasants were caught up in economic and legal dependency from their lords. Gradually any migration was banned. Peasants tied to their place of residence were exempted from military service (but not from the general territory guarding) and at the beginning of the 16 th century the prohibition to carry weapons entered into force as landlords were afraid of armed peasants. This prohibition had far-reaching consequences - later, when the landlords needed the help of farmers to protect the territory, they no longer knew how to use weapons, and also were unwilling to do it. The development of serfdom was a lengthy process, and in fact only in the 18th century it entered the stage when the peasant with his own body and property was considered as a complete property of the landlord. A classical example of that is the Declaration of Rozen. Serfdom in Latvia was abolished in the 19th century as the law on the peasants' liberation was adopted (in Kurzeme - in 1817, in Vidzeme - in 1819, in Latgale - in 1861). However, even after the peasant liberation in Kurzeme and Vidzeme, the nobles tried to maintain certain provisions of serfdom" (Tilde Encyclopaedia of Latvian History, 1998-2012b).

Phenomenon similar to serfdom was common in the ancient world (Kḷaviņš, 2012, p. 96): "Helotes state in Sparta was similar to medieval serfs. In Roman Empire in the 3rd century AD, due to lack of manpower land was leased to farmers, called coloni. Coloni began to replace slaves, but their conditions became worse, and in year 332, Emperor Constantine I issued the law that tied colons to the land. The decisive factor of the serfdom's severity was the fact that the landlords obtained with the feud the highest judicial power over peasants that gave vassals almost unlimited influence on other issues too. Unlike Swabia, where it happened, in Livonia this judicial power was reserved by landlords for themselves. The situation changed after the collapse of Livonia when the basic principles of serfdom in Vidzeme were formulated by Claudius Tots - Governor General of Charles X, but in the Duchy of Kurzeme and in Latgale - 'Polish Livonia' (Infanty Polskie), medieval feudal system and management of the German Order was replaced by the power of landlords" (Kḷaviņš, 2012).

Consequently, after the abolition of serfdom, the nobility was no longer responsible for peasant taxes, public works and mutual assistance, these issues became the responsibility of peasants themselves.For this reason, the institution of parishes was restored that in Livonia had already existed in the Middle Ages (known as the "vaka") by adoption of the law on parishes' self-governments in 1866, that was more liberal than in Prussia (from 1856) or in Russia (from 1861); the life of Vidzeme peasants considerably changed and peasants themselves were responsible for the payment of taxes, giving recruits, road repair, troop 
accommodation, care for elderly and sick, wage setting, budget discussions, election of the parish school teacher etc. (Kḷavinš, 2012, pp. 103-104).

In the 18th century, thanks to the outstanding Baltic enlightenment employees, the idea of mutual social assistance was implemented in Vidzeme Charitable and Economic Society founded in 1792 whose spiritual father was a scientist of French origin Georg Friedrich Parrot (George-Frédéric Parrot, 1767-1852). Being a tutor in Cesis, Parrot called nobles to take care of farmers, improving not only their social standing and holdings, but also providing health care, thus Vidzeme, and especially Cesis, situated not far away from Piebalga, became one of the first places in the world where the ideas of modern social society were formulated and later implemented in Germany of Bismarck as well as in the independent Republic of Latvia. The Charitable and Economic Society as the environmental and regional development fund still exists nowadays in Germany (Kḷavinš, 2012, p. 104).

In 1858, the railway line between Dvinsk (Daugavpils) and Riga was built, which speeded up the trade development and the development of the city as a whole (Klaviņš, 2012, p. 106). Then the rapid trade development, the industrialization period, and the urbanization process followed.

In the 19th century, the Latvian agrarian society turned into urban (in 1897, $30 \%$ of the population lived in urban areas), in 1914, $29 \%$ of the total population lived in urban areas, each town had a population of 100000 people or even more. Latvia became the most intensively urbanized European region (only the United Kingdom with $35.5 \%$ was ahead of Latvia). In the 90s of the 19th century, only $2 \%$ of enterprises were employing less than 100 workers, $50 \%$ were employing 100 to 1000 workers, while $30 \%$ of companies were employing more than 1000 workers (Kḷaviňš, 2012, p. 106).

The end of the 19th century and the beginning of the 20th century was the time of rapid construction, buying and evaluation in Riga and other major Baltic States. People were interested in moving to the centres of the cities, to establish and open their businesses. The land properties of the farmers were better positioned if they were close to the cities. That was caused by the faster market sale and easier availability (Kḷavin,š, 2012, p. 107).

Multinational Baltic metropolis in Riga determined the intensity of construction of Art Nouveau buildings and the proportion of national romanticism in it. The wealthier peasants and workers of the city invested their capital in the construction of new wooden buildings, becoming the landlords, who rented apartments, the traders or the owners of small stores and plants (Kḷaviņš, 2012, p. 107).

In Old Riga - Inner Riga - each foot of land was of enormous value. With growing number of inhabitants, space per inhabitant diminished (Kolbergs, 1998, p. 10). There were a number of famous and important objects in the Old Town, such as House of the Blackheads, the Dome, the Latvian National Opera, St. Peter's Church, Central Market, etc. The development and flourishing of Art Nouveau and urban architecture was also facilitated by the fact that in the beginning of the 20th century it was not allowed to build similar buildings in Latvia. Later, economic political situation changed, which also affected the real estate market. In 1914, there were 2552 thousand inhabitants in the Latvian territory, and only 1596.1 thousand inhabitants in 1920 - almost 1 million inhabitants were the biggest economic loss 
caused to Latvia by the World War I. There were 520 thousand inhabitants in Riga in 1914, whereas, only 225 thousand inhabitants in December of 1920 (Zalts, 1938). The World War I destroyed most of the Latvian territory, industry was disorganised but monetary development followed (Karnups, 2012). Latvia as a state was established without its own money; various means of payment were circulating Deutschemarks, Ostmarks, Ostroubles, Tsar rubles. Money was issued in the period from 18 November 1918 to 1 April 1920 in the amount of 37.9 million LVL, which corresponded to $58.5 \%$ of revenue, and the "Law on the Only Means of Payment and Settlement of the Earlier Debts and Contracts" of 18 March 1920 turned the Latvian ruble into the only means of payment in Latvia. However, the Latvian ruble continued losing its value against other currencies, and the government tried to stabilize it. The Law of 18 March 1920 was amended on 20 June 1921. The amendment announced that the transactions should be made and taxes should be paid in Latvian rubles or gold Francs. On 3 August 1922, the Minister of Finance Ringolds Kalnings signed the "Regulations on the Money". 50 Latvian rubles were set to 1 Latvian lat.

The global economic crisis in the 4th quarter of 1930 was replaced by the economic growth period in Latvia, where it started later because the Latvian-USSR trade agreement of 1927 was still active, and the crisis mostly affected the banks, because the banks did not have large real estates, and the poor economic conditions caused many bankruptcies (Karnups, 2012, p. 29).

In the course of the crisis, the first national income calculations amounted to 1.151 million LVL (LVL 600 per capita), but in 1932 they decreased by $35 \%$ to 744 million LVL (LVL 390 per capita). Nevertheless, A. Ceihners considered that by taking into account the money values and other changes, the real national income decline was much less (10-12\%) (Karnups, 2012, p. 36).

The total numbers of bankruptcies in Latvia in the period from 1927 to 1934 are presented in Table 8 .

Table 8. Bankrupted companies and announced auctions in Latvia (1927-1934) (Karnups, 2012, p. 29)

\begin{tabular}{|l|l|l|l|l|l|l|l|l|}
\hline Number/year & 1927 & 1928 & 1929 & 1930 & 1931 & 1932 & 1933 & 1934 \\
\hline $\begin{array}{l}\text { Bankrupted } \\
\text { companies }\end{array}$ & 114 & 90 & 117 & 82 & 162 & 249 & 129 & 129 \\
\hline $\begin{array}{l}\text { Announced } \\
\text { auctions }\end{array}$ & 577 & 1061 & 1694 & 2562 & 2732 & 3090 & 5425 & 7077 \\
\hline
\end{tabular}

Taking into account the relatively high proportion of local resources in Latvian export (large part consisted of agricultural goods and timber), as well as significant volume of export to the countries which had previously abandoned the gold standard, the rate of the Latvian lat was pegged to the British pound sterling, which actually meant devaluation. The world trade recovery from economic crisis contributed to the Latvian foreign trade, and in the first year after devaluation the export price index increased most of all (by 60 points), but still, in spite of the 
important customs changes, the import price index increased by 24 points (Karnups, 2012).

The establishment of the Bank of Latvia and implementation of national currency on the basis of the gold standard stabilized the banking and financial system and ensured the attraction of foreign capital; especially the agriculture was developing, and the agrarian reform was of great importance, which contributed to the transition to intensive agriculture (Karnups, 2012, p. 38).

The income distribution issues were significant. The Soviet government in Latvia tried not to convert all the production means into public assets in order to compare all the propertied classes, and already on 31 January 1919, the Soviet government in Latvia issued a decree on the imposition on the propertied classes of a special, very heavy duty, and the following subjects were taxed (Aizsilnieks, 1968, pp. 90-93):

1. Capital and war profit over the past four years, if they exceeded 20000 rubles. If the capital or the mentioned profit amounted to 20000 to 30000 rubles, the tax was $5 \%$. An increase in capital or profit caused rapid increase in tax rate up to $100 \%$, if the capital or profit amounted to 500000 rubles or more.

2. Real estate in the cities, if the value exceeded a certain amount. The real estate in Riga of value more than 20000 rubles was subject to this tax. If the value was from 20000 to 50000 rubles, $2 \%$ of the value had to be paid. The tax rate was increasing along with the rise in the real estate value, until the value reached 300000 rubles, and the tax was $8 \%$ of the value, while the real estate was confiscated. The value of the real estate, which was the condition for confiscation of the real estate, was lower in other Latvian cities than in Riga.

3. Rural real estates, if they were less than 13 ha, were free from the tax. The tax for the real estate from 13 to 18.5 ha amounted to 50 rubles. The tax for the real estate from 18.5 to 27.8 ha amounted to 200 rubles. The tax for the real estates, which exceeded 111.1 ha, was 20 rubles for each 1/3 ha, and the real estate was confiscated. All property, both real as movable, was confiscated, except for the most necessary items for life.

4. Trade and industrial companies, which were divided into 4 groups, wherein the first group had to pay $1 \%$, while the fourth group had to pay $10 \%$ of previous year's turnover.

5. Private income of the representatives of liberal professions (doctors, lawyers, architects, etc.), if it exceeded 6000 rubles per year. If this income was 6000 to 10000 rubles, $10 \%$ had to be paid on the part of the income, which excessed 6000 rubles. The tax rate was gradually increasing. When the annual income exceeded 30000 rubles, the tax had to be paid on the part of the income, which exceeded 15000 rubles.

Particular benefits were intended for those who were not paying the tax in cash but with goods, such as wool, woolen cloth or gold. They had to pay only one-tenth of the prescribed amount of tax. Those persons, who were paying the tax with 
cereals, potatoes, beans, hemp, linseed, poultry, eggs, meat or dairy products, had to pay only one-sixth of the prescribed amount of tax (Aizsilnieks, 1968, pp. 9093). The Soviet Russia decree of 26 March 1919 cancelled the priority of succession both by law and under will, henceforth the only legal successor was the state. Only the relatives of the low-income people's assets, value of which did not exceed 10 000 rubles and consisted of "furniture and tools, could succeed" (Aizsilnieks, 1968, pp. 90-93).

It was mentioned that the relationship of authorities and people, especially Ulmanis and low-income social strata, in the public space was built in a patriarchal perspective, ensuring the national social policy providing emotionally (kindness, concern, care) and traditionally sound life (Zelče, 2008).

The partial real estate denationalisation took place in 1941. Until the end of 1942, 238 small trading companies were denationalized, of which 174 were involved in trade of goods, 55 in entertainment and 9 in health care, hygiene and cleaning (Aizsilnieks, 1968, pp. 894-897). As of September 1941, Riga was managing 7252 apartment buildings with 77674 apartments and 2.9 million $\mathrm{m}^{2}$ of living space (Aizsilnieks, 1968, pp. 941-943).

A number of events took place in the 20th century, and on 30 December 1991, the USSR was disbanded (the Latvian State Archive, 1998), and the process of denationalisation began.

Along with the restoration of Latvian independence, the provisions of the Civil Law of 1937 were restored, by which the property rights were of great importance, including the real estate recording and consolidation of the related rights in the Land Register.There were 340 real estates recorded in 1993, 74828 real estates were recorded in 2003, but in 2011, the number of real estates recorded in the Land Registers reached 1.16 million units (State Unified Computerized Land Register, 2016).

There are 26 District (city) Land Register Offices operating in Latvia, and 86 judges are employed there. Decision-making and process of issuance of the documents is fully computerized - this means that the information is stored in the journals and land register divisions as an electronic database, providing the data representation on the computer screen, and the content is printed and issued to the visitors in paper form (State Unified Computerized Land Register, 2016). The most significant events of the development of the State Unified Computerized Land Register are presented in Table 9.

Real estate development is a continuous process, so the new tendencies, which will take place in the real estate market and the economy, are very significant. Therefore, the everyday events are writing history, and the future development will be seen over time. 
Table 9. The most significant events in the development of the State Unified Computerized Land Register (2016)

\begin{tabular}{|c|c|}
\hline Year & Event \\
\hline 1993 & $\begin{array}{l}\text { The Land Register Act was updated, the operation of the Land Registry } \\
\text { commenced and the first computers were acquired in the framework of the } \\
\text { World Bank project }\end{array}$ \\
\hline 1995-1998 & $\begin{array}{l}\text { PHARE project for the development and implementation of the software for the } \\
\text { Land Register local database }\end{array}$ \\
\hline 1998.10.22. & $\begin{array}{l}\text { Land Register Law was supplemented with the chapter "Computerized Land } \\
\text { Register" }\end{array}$ \\
\hline 1999,2001 & $\begin{array}{l}\text { State order for the development of the State Unified Computerised Land } \\
\text { Register }\end{array}$ \\
\hline 2001 & Commissioning of the State Unified Computerised Land Register system \\
\hline 2002 & Eectronic data receivedfor the Population Register \\
\hline 2002 & Electronic settlements for the received services in online bank \\
\hline 2003 & Electronic exchange of data with the Commercial Registers \\
\hline 2003 & $\begin{array}{l}\text { Electronic settlements for the received services over the Internet with } \\
\text { credit/debit cards }\end{array}$ \\
\hline 2004 & $\begin{array}{l}\text { Initiation of cooperation with SIA "Lursoft" on the distribution of the land } \\
\text { register information }\end{array}$ \\
\hline 2004 & $\begin{array}{l}\text { Electronic data exchange with Ventspils City Council on real estate tax } \\
\text { recording }\end{array}$ \\
\hline 2006 & Electronic data exchange with Riga City Council on real estate tax recording \\
\hline 2007 & Implementation of electronic distribution of files \\
\hline 2007 & Introduction of data exchange with the information system of the Court \\
\hline 2007 & $\begin{array}{l}\text { Implementation of electronic data exchange with the State Land Service - no } \\
\text { cadastral certificate is required }\end{array}$ \\
\hline 2008 & $\begin{array}{l}\text { Electronic data exchange with the Daugavpils City Council on real estate tax } \\
\text { recording }\end{array}$ \\
\hline 2008 & $\begin{array}{l}\text { Introduction of e-service "My data in the State Unified Computerised Land } \\
\text { Register" }\end{array}$ \\
\hline 2009 & $\begin{array}{l}\text { Introduction of the data exchange with more than } 50 \text { municipalities on the real } \\
\text { estate tax recording }\end{array}$ \\
\hline 2013 & $\begin{array}{l}\text { Implementation of ERDF funded project "Preparation of the Archives of the } \\
\text { Ministry of Justice and its Subordinated Institutions for the Provision of } \\
\text { Electronic Services - Stage 1", which has resulted in the improvement of } \\
\text { VVDZ information system }\end{array}$ \\
\hline
\end{tabular}

\section{CONCLUSION}

Various problems have always existed in the economy, society and real estate market. Interestingly, the development has over time also contributed to inequality. Limited resources and unlimited needs have always existed. Inequality and fair income distribution issues have been present throughout the history. 
Economic problems have existed in the course of human development, and it is very difficult to achieve the satisfaction of all members of the society and high standard of living. At the same time, an optimal balance between the government regulation and free market regulation should be found, which would be appropriate for the sustainable development of the society. Land and real estate are the main components of the material socioeconomic base, therefore all land redistribution issues were always important and significant for the development of the society. The real estate was always related to the economic, social, ecological, technological, political and legal issues. In any case, the society should strive for the sustainable development of the economy and the real estate market.

Sustainability can be analysed on different levels. A developed multilevel sustainability concept for real estate market is planned to be done in future studies.

\section{REFERENCES}

Active Anglo Chinese Communications. (2016). Retrieved from http://www.activeukchina.com/china-overview/china-economic-history/

Aizsilnieks, A. (1968). Latvian farm history, 1914-1945 (5th ed.). Latvijas saimniecības vēsture, 1914-1945 (5. sējums). Stockholm: Daugava.

Akaev, A. (2010). Ciklicheskie kolebanija v ekonomike $i$ upravlenie dinamikoj ekonomicheskogo razvitija s pomoshhju tehnologicheskih sdvigov. [Cyclical fluctuations in the economy and management of the dynamics of economic development through technological shifts]. Retrieved from gov.cap.ru/home/15/elena/innovazii/huv\%20bio/zik.ppt

Ames, G. J. (2004). Mercantilism. In Europe, 1450 to 1789: Encyclopedia of the Early Modern World. Retrieved from http://www.encyclopedia.com/topic/mercantilism.aspx

Archer, R. (2016). Petra. Retrieved from http://ssqq.com/archive/petra.htm

Biart, M. (2002). As cited in Colontonio, A. (2009). Social sustainability: a review and critique of traditional versus emerging themes and assessment methods. In M. Horner, A. Price, J. Bebbington \& R. Emmanuel (Eds.), SUE-Mot Conference 2009: Second International Conference on Whole Life Urban Sustainability and its Assessment: conference proceedings. Loughborough: Loughborough University (pp. 865-885). Retrieved from http://eprints.lse.ac.uk/35867/1/Colantonio_Social_sustainability_review_2009.pdf

Brīvers, I. (2009). Ko varam mācīties no ekonomikas vēstures? [What Can We Learn from Economic History?] In Latvijas tautsaimniecības pagātne, tagadne un perspektīvas [Past, Present and Prospects of Latvian Economy] (pp. 5-14). Riga: RTU Press.

Bruksle, I. (2013). Cenu veidošanas būtība mainīgajā uzṇēmējdarbības vidē [Pricing essence in a changing business environment]. In V. Zariņa \& S. Begečs (Eds.), Uzṇēmējdarbības vide un tās attīstības aspekti: monogrāfija [Business environment and its development aspects: monograph] (pp. 71-109). Riga: Business High School Turība.

CERES, IIGCC, INCR, PRI, UNEP Finance Iniciative, RICS. (2016). Sustainable Real Estate investment. Implementing the Paris Climate Agreement: An Action Framework. Retrieved from http://www.unepfi.org/fileadmin/documents/SustainableRealEstateInvestment.pdf

Cēsis Municipality webpage. (2016). Vēsturiskā attīstība [Historical development]. Retrieved from http://old.cesis.lv/?p=11

Chan Wing, S. N. C., Canha, D., \& Pretorius. J. H. C. (2015). Residential Solar Water Heating Measurement and Verification Case Studies. Proceedings of the 8th International Conference on Energy Efficiency in Domestic Appliances and Lighting. Retrieved from http://iet.jrc.ec.europa.eu/energyefficiency/sites/energyefficiency/files/events/EEDAL15/S15_ Heating-cooling-1/eedal15_submission_90.pdf

Clayton, P. A., \& Price, M. (1988). The Seven Wonders of the Ancient World. London: Routledge.

CrossBorder Capital Ltd. (2012). Global Liquidity Indexes. Retrieved from http://www.liquidity.com/Docs/Global_Liquidity_Indexes_(GLI)_2012_Data.pdf 
Deineka, L. N. (2006). Ekonomicheskie cikly [Economic Cycles]. In V. E. Lankin (Ed.), MARKETING: Uchebnoe posobie dlja podgotovki $k$ itogovomu mezhdisciplinarnomu ekzamenu professionalnoj podgotovki marketologa [MARKETING: A manual for the preparation of to the final interdisciplinary exam training in marketing]. Retrieved from http://www.aup.ru/books/m99/1_26.htm

Ding, G. K. C. (2012). Summary of Environmental Assessment Tools for Buildings. In Christian N. Madu \& Chu-Hua Kuei. (Eds.), Handbook of sustainability management (pp. 451-453). Singapore: Hackensack, NJ: World Scientific.

Frini, A., \& BenAmor, S. (2015). A TOPSIS multi-criteria multi-period approach for selecting projects in sustainable development context, Proceedings of 2015 International Conference on Industrial Engineering and Operations Management, March 3-5, 2015, (pp. 1-9). http://dx.doi.org/10.1109/IEOM.2015.7093900

Gods, U. (2002). Makroekonomika [Macroeconomics]. Riga: Business High School Turība.

Grizāns, J. (2015). Competitiveness of the Business Environment in Latvian Urban Areas and Applicable Tools for its Improvement. Riga: RTU Press.

Hanke, S. H. (2010). The Great 18-Year Real Estate Cycle. Globe Asia. Retrieved from http://www.cato.org/publications/commentary/great-18year-real-estate-cycle

Heinrich, J., Bazeler, U., Sabov, Z., \& Koch, V. (2000). Osnovy ekonomicheskoj teorii, principy, problemy, politika. Germanskij opyt $i$ Rossijskij put [Basic economic theory principles, problems, politics. German and Russian experience]. St. Petersburg: Piter.

Heniņš, A. (2007). The Riga Chronicle. Riga: Rīgas balvas biedrība.

Homer. (n.d.). The Iliad. Retrieved from http://www.online-literature.com/homer/iliad/

Homer. (n.d.). The Odyssey. Retrieved from http://www.online-literature.com/homer/odyssey/

Hornblower, S., \& Spawforth, A. (2001). The Oxford Classical Dictionary. USA: Oxford University Press.

Huntington, S. P. (1971). The Change to Change: Modernization, Development, and Politics. Comparative Politics, 3(3), 283-322. http://dx.doi.org/10.2307/421470

Juglar, C. (1862). Des crises commerciales et de leur retour périodique. Retrieved from http://gallica.bnf.fr/ark:/12148/bpt6k1060720

Karnups, V. P. (2012). Latvijas tautsaimniecības un finanšu norises (1920-1940) [Latvian economic and financial developments (1920-1940)]. Retrieved from https://www.bank.lv/images/stories/pielikumi/publikacijas/citaspublikacijas/Karnups.pdf

Kauškale, L., Geipele, I., \& Riemenschneider, F. (2016). Contemporary Sustainable Development Problems of Construction Industry: Case of Latvia. In Proceedings of Research World International Conference (pp. 5-11). Singapore, March 4, 2016. Khandagiri, Bhubaneswar.

Keynes, J. M. (1936). The General Theory of Employment, Interest and Money. Retrieved from http://cas.umkc.edu/economics/people/facultypages/kregel/courses/econ645/winter2011/genera ltheory.pdf

Khalil, E. L. (2001). Adam Smith and Three Theories of Altruism. Louvain Economie Review, 67(4), 421-435. http://dx.doi.org/10.3917/rel.674.0421

Khan, E. (2016). 10 Oldest Continuosly Inhabited Cities. Retrieved from http://www.wonderslist.com/10-oldest-continuously-inhabited-cities/

Kitchin, J. (1923). Cycles and Trends in Economic Factors. Review of Economics and Statistics, 5(1), 10-16. http://dx.doi.org/10.2307/1927031

Kḷaviņš, K. (2012). Politikas un ìpašuma filozofija [Philosophy of Politics and Property]. Scientific Monograph. Riga: RTU Press.

Kolbergs, A. (1998). The story of Riga: History of Riga, Old Town. Riga: Jāņa sēta.

Koltashov, V. (2010). Volny Kondrateva [Kondratjev waves]. Retrieved from http://www.finansy.ru/st/post_1265710843.html

Kondratieff, N. D., \& Stolper, W. F. (1935). The Long Waves in Economic Life. The Review of Economics and Statistics, 17(6), 105-115. http://dx.doi.org/10.2307/1928486

Kondratieff, N. D. (1922). Mirovoe hozjajstvo i ego konjunktury vo vremja i posle vojny [World economy and environment during and after the war]. In Vologda: Trudy konjukturnovo instituta pri Petrovskoy s.-h. akad. [Vologda: Proceedings of Conjuncture Inst. at Petrovsky. agricultural acad.]. 
Korotayev, A. V., \& Tsirel, S. V. (2010). A Spectral Analysis of World GDP Dynamics: Kondratieff Waves, Kuznets Swings, Juglar and Kitchin Cycles in Global Economic Development, and the 2008-2009 Economic Crisis. Structure and Dynamics, 4(1). Retrieved from http://escholarship.org/uc/item/9jv108xp\#page-3

Krilovs, L. (2014). Ekonomiskās domas retrospekcija [Restospection of economic thought]. Scientific Monograph. Riga: RTU Press.

Kuznets, S. (1930). Secular Movements in Production and Prices. Their Nature and their Bearing upon Cyclical Fluctuations. Boston: Houghton Mifflin.

LaHaye, L. (2014). Mercantilism. In The Concise Encyclopedia of Economics. Retrieved from http://www.econlib.org/library/Enc/Mercantilism.html

Littig, B., \& Grießler, E. (2005). As cited in Colantonio, A. (2009). Social sustainability: a review and critique of traditional versus emerging themes and assessment methods. In M. Horner, A. Price, J. Bebbington \& R. Emmanuel (Eds.), SUE-Mot Conference 2009: Second International Conference on Whole Life Urban Sustainability and its Assessment: conference proceedings (pp. 865-885). Loughborough: Loughborough University. Retrieved from http://eprints.1se.ac.uk/35867/1/Colantonio_Social_sustainability_review_2009.pdf

Ludza municipality webpage. (2016). Ludzas pilsēta [City of Ludza]. Retrieved from http://www.ludza.lv/ludzas-novads/ludzas-pilseta/

Mark, J. J. (2014). The Ancient City. In Ancient History Encyclopedia. Retrieved from http://www.ancient.eu/city/

Marshall, A. (1890). Principles of economics (8th ed.). London: Macmillan. Retrieved from http://oll.libertyfund.org/titles/1676

Maslow, A. H. (1954). Motivation and Personality (3rd ed.). New York: Harper \& Raw. Retrieved from http://psy2.ucsd.edu/ nchristenfeld/Happiness_Readings_files/Class\%207\%20\%20Maslow\%201954.pdf

Menshikov, S. M., \& Klimenko, L. A. (1989). Dlinnye volny v jekonomike: kogda obshhestvo menjaet kozhu [Long Waves in Economics: when Society Changes its Skin]. Moscow: Mezhdunarodnie otnoshenija.

Nefedov, S. A. (2004). Introduction to Social Macrodynamics: Secular Cycles and Millennial Trends (pp. 37-46). Moscow: KomKniga/URSS. Retrieved from http://cliodynamics.ru/download/Korotayev_Secular_Cycles_Chapter1.pdf

Ovechkina, N. I., \& Shulgina, N. A. (2012). Teorija ciklicnosti v istorii I demokratii [Cyclicity Theory in Economics and Demography]. Vestnik NSUEM, 2, 105-110.

Paegle, L. (1924). Ievads vēsturē [An introduction to the history]. Riga: Valters un Rapa Issue. Riga: Zvaigzne, 1991.

Pilsēta [City]. (2016). In History Encyclopaedic Dictionary. Retrieved from http://vesture.eu/index.php/Pils\%C4\%93ta

Polese, B., \& Stren, R. (2000). As cited in Colantonio, A. (2009). Social sustainability: a review and critique of traditional versus emerging themes and assessment methods. In M. Horner, A. Price, J. Bebbington \& R. Emmanuel (Eds.), SUE-Mot Conference 2009: Second International Conference on Whole Life Urban Sustainability and its Assessment: conference proceedings (pp. 865-885). Loughborough: Loughborough University. Retrieved from http://eprints.1se.ac.uk/35867/1/Colantonio_Social_sustainability_review_2009.pdf

Ricardo, D. (1817). On the Principles of Political Economy and Taxation. London: John Murrey. Retrieved from http://www.econlib.org/library/Ricardo/ricP1a.html

Sachs, I. (1999). As cited in Colantonio, A. (2009). Social sustainability: a review and critique of traditional versus emerging themes and assessment methods. In M. Horner, A. Price, J. Bebbington, \& R. Emmanuel (Eds.), SUE-Mot Conference 2009: Second International Conference on Whole Life Urban Sustainability and its Assessment: conference proceedings (pp. 865-885). Loughborough: Loughborough University. Retrieved from http://eprints.1se.ac.uk/35867/1/Colantonio_Social_sustainability_review_2009.pdf

Schumpeter, J. A. (1939). Business Cycles. A Theoretical, Historical and Statistical Analysis of the Capitalist Process. Retrieved from

http://classiques.uqac.ca/classiques/Schumpeter_joseph/business_cycles/schumpeter_business_ cycles.pdf 
Smirnov, A. S. (2012). Why are there no more Kondratiev large cycles? Voprosi Upravlenija, Retrieved from http://vestnik.uapa.ru/en/issue/2012/04/09/

Smith, A. (1776). An Inquiry into the Nature and Causes of the Wealth of Nations (5th ed.). London: Methuen \& Co., Ltd., 1904. Retrieved from http://www.econlib.org/library/Smith/smWN.html

Spekke, A. (1935). Latvieši un Livonija [Latvians and Livonia]. Riga: Zinātne, 1995.

State Unified Computerized Land Register. (2016). Apraksts un vēsture [Description and history]. Retrieved from https://www.zemesgramata.lv/?cid=13

Stoner, J. A. F., \& Freeman, R. E. (1989). Strategic Management: Theory and Practice (2nd ed.). London: Thomson Learning.

The Editors of Encyclopædia Britannica. (2015). 7 Wonders of the World. In Encyclopaedia Britanica. Retrieved from http://www.britannica.com/topic/Seven-Wonders-of-the-World

The Telegraph. (2016a). The worlds 20 oldest cities. Retrieved from http://www.telegraph.co.uk/travel/galleries/The-worlds-20-oldest-cities/syria-damascus/

The Telegraph. (2016b). What are the seven wonders of the world? Retrieved from http://www.telegraph.co.uk/travel/advice/What-are-the-seven-wonders-of-the-world/

The World of Wonders. (2016). 7 Wonders of the Medieval World. Retrieved from http://www.theworldwonders.com/medievalwonders.html

Tilde Encyclopaedia of Latvian History. (1998-2002a). Pirmo cilvēku ienākšana Latvijas teritorijā [First people entering the Latvian territory]. In Tildes Datorenciklopēdija Latvijas Vésture [Tilde Encyclopaedia of Latvian History]. Retrieved from http://www.letonika.lv/groups/default.aspx?cid=31313

Tilde Encyclopaedia of Latvian History. (1998-2002b). Dzimtbūšana [Serfage]. In Tildes Datorenciklopēdija Latvijas Vēsture [Tilde Encyclopaedia of Latvian History]. Retrieved from http://www.letonika.lv/groups/default.aspx?cid=31469

Tsoulfas, G. T., \& Pappis C. P. (2012). Supply Chains and Sustainability. In Christian N. Madu \& Chu-Hua Kuei (Eds.), Handbook of sustainability management. (pp. 335-352). Singapore: Hackensack, NJ: World Scientific. http://dx.doi.org/10.1142/9789814354820_0016

UN Global Compact, RICS. (2015). Advancing Responsible Business in Land, Construction and Real Estate Use and Investment. Retrieved from http://crnavigator.com/materialy/bazadok/429.pdf

United Nations Population Division. (2001). The World at Six Billion. Retrieved from http://www.un.org/esa/population/publications/sixbillion/sixbilpart1.pdf

United States Census Bureau. (2016). World Population. Retrieved from http://www.census.gov/population/international/data/worldpop/table_history.php

Vanags, J. (2010). Real Estate Economics. Riga: RTU Press.

Veblen, T. (1899). The Theory of Leisure Class. Retrieved from http://moglen.law.columbia.edu/LCS/theoryleisureclass.pdf

Violatti, C. (2014). Zhou Dynasty. In Ancient History Encyclopedia. Retrieved from http://www.ancient.eu/Zhou_Dynasty

World of New 7 Wonders. (2016). New 7 Wonders of the World. Retrieved from http://world.new7wonders.com/?n7w-page=new7wonders-of-the-world

Worldometers. (2016). World population: Past, Present and Future. Retrieved from http://www.worldometers.info/world-population

Zalts, A. (1938). Nacionālā saimniecība 20 gados: Centieni un sasniegumi. Riga: Pagalms. Retrieved from https://www.bank.lv/images/stories/pielikumi/publikacijas/citaspublikacijas/Karnups.pdf

Zelče, V. (2008). Sagaidot 1940. gadu: ieskats Latvijas iedzīvotāju vēstulēs prezidentam [In anticipation of 1940: insight into the Latvian population letter to President]. Latvian Archives. History, 4, p. 123. Retrieved from http://www.arhivi.lv/sitedata/ZURNALS/zurnalu_raksti/Zekce.pdf

Zuleeg, F. (2010). European Economic Sustainability Index. Retrieved from http://www.epc.eu/documents/uploads/pub_1127_eesi.pdf 


\section{AUTHORS' SHORT BIOGRAPHIES}

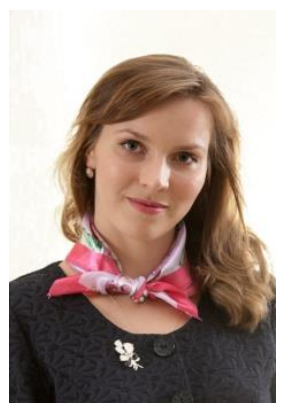

Linda Kauškale, $\mathrm{Mg}$. oec., is a lecturer, a $\mathrm{PhD}$ student and an assistant researcher with the Institute of Civil Engineering and Real Estate Economics, Faculty of Engineering Economics and Management, Riga Technical University. She obtained Professional Master Degree with distinction in Civil Construction and Real Estate Management and has the qualification of Real Estate Economist, as well as extensive practical experience. She has participated in international scientific conferences in United Arab Emirates, Malaysia, Singapore, Lithuania, and others. Her research areas are real estate market and macroeconomic analysis, business cycle, sustainable construction, decision making, environmental development. She is a professional member of Industrial Engineering and Operations Management Society. In autumn of 2013 she was FIABCI scholar.

ORCID iD: http://orcid.org/0000-0002-0280-2977

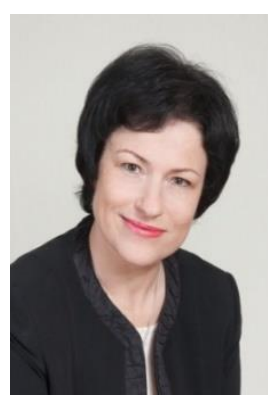

Ineta Geipele is a Professor with the Faculty of Engineering Economics and Management, Director of the Institute of Civil Engineering and Real Estate Economics, Head of the Chair of Civil Construction and Real Estate Economics and Management of Riga Technical University (RTU), Latvia. She obtained Doctor's degree in Economics and Master's degree in Economics in Engineering Sciences from RTU. She improved her professional skills in Austria, Germany, Denmark and England. She is an author and co-author of more than 284 scientific publications. Her current research areas are sustainability development problems of real estate market, construction industry, land use management and institutional economics. She is an expert on management science of the Latvian Council of Science, a board member of the FIABCI-Baltic Multinational Chapter and of the Cunfte of the Facility Management of Latvian Housing, and a member of the Latvian Union of Civil Engineers.

ORCID iD: http://orcid.org/0000-0002-2963-087X 